\title{
The Ecosystem Approach and the Common Fisheries Policy
}

\author{
Jill Wakefield
}

The current regulation implementing the EU Common Fisheries Policy (the Fisheries Regulation) observes that an ecosystem-based approach to fisheries management needs to be implemented and environmental impacts of fishing activities should be limited. ${ }^{1}$ Accordingly, the objectives of the Common Fisheries Policy (CFP) require the implementation of an ecosystem-based approach to management to 'minimise' the negative impacts of fisheries on the marine environment, but its application is to do no more than 'endeavour' to avoid the degradation of the marine environment. ${ }^{2}$ Action under the CFP according to the ecosystem-based approach requires an 'integrated approach' to fisheries management, to maintain fisheries 'within ecologically meaningful boundaries'. ${ }^{3}$ Ideally, 'the CFP should contribute to the protection of the marine environment ... in particular to the achievement of good environmental status by 2020', and it is required to be 'coherent with the Union environmental legislation' with regard to good environmental status. ${ }^{4}$

In adopting the latest action plan for environmental protection, the European Parliament and Council express concern at the loss of natural capital in

1 Regulation(EU) No 1380/2013 of the European Parliament and of the Council on the Common Fisheries Policy, amending Council Regulations (EC) No 1954/2003 and (EC) No 1224/2009 and repealing Council Regulations (EC) No 2371/2002 and (EC) No 639/2004 and Council Decision 2004/585/EC, [2013] OJ L354/22, Recital 13.

2 Regulation 1380/2013, Article 2(3).

3 Regulation 1380/2013, Article 4(1)(9).

4 Regulation 1380/2013, Article 2(5)(j). Environmental legislation explains good environmental status as: 'the environmental status of marine waters where these provide ecologically diverse and dynamic oceans and seas which are clean, healthy and productive within their intrinsic conditions, and the use of the marine environment is at a level that is sustainable, thus safeguarding the potential for uses and activities by current and future generations'. Directive 2008/56/EC of the European Parliament and of the Council of 17 June 2008 establishing a framework for community action in the field of marine environmental policy (Marine Strategy Framework Directive), [2008] OJ L164, Article 3(5).

(C) JILL WAKEFIELD, 2019 | DOI:10.1163/9789004389984_011

This is an open access chapter distributed under the terms of the prevailing CC-BY-NC License at the time of publication. 
European biodiversity, including marine ecosystems, despite the wide panoply of measures adopted to protect the environment. ${ }^{5}$ So serious has been the degradation of EU waters, principally as a result of overfishing, that their ability to continue to supply essential goods and services is in doubt. The challenge is to ensure that the exploitation of resources 'is compatible with the conservation and sustainable management of marine and coastal ecosystems. ${ }^{6}$ However, devising and embedding a system that would be capable of redressing the situation is hampered by the disjuncture between two crucial areas of EU policy: fisheries and the environment. A holistic ecosystem-based approach to the management of marine areas as prescribed in the latest Fisheries Regulation has not been deployed to conserve and protect ecosystems and biodiversity. Instead, the precautionary approach to fisheries management has been retained and the sustainability of living marine resources remains precarious.

The route to ecologically sustainable fisheries in the EU lacks a cogent plan and is impeded by inappropriate economic objectives and ill-conceived regulation. Fisheries regulation, designed under the auspices of agricultural policy, is not fit for the control of an extractive industry. The 'harvesting' of stocks to the margin of sustainability causes continual ecological stress and leads to the degradation of EU waters. Meanwhile, the costs of maintaining the fisheries industry in an economically and environmentally untenable position falls upon EU taxpayers. Fisheries policy should integrate environmental protection but, in practice, economic imperatives trump restrictions on fishing activity other than in exceptional cases. Following the latest reform of governance of the fisheries sector, the economic interests of the fishing industry will continue to predominate over ecosystem protection. This chapter considers why the EU's more forward-thinking ecosystem-based management has failed to find traction under the CFP and why achieving good environmental status for EU waters, as currently defined, may not render EU seas resilient and productive.

\section{Good Environmental Status for EU Waters}

In the EU's seventh environmental action programme (EAP) entitled 'Living well, within the limits of our planet,' ${ }^{7}$ marine ecosystems are described as

5 Decision No 1386/2013/EU of the European Parliament and of the Council of 20 November 2013 on a General Union Environment Action Programme to 2020 'Living well, within the limits of our planet' [2013] OJ L354/171, (7th Environmental Action Plan), Recitals 17-19.

6 Decision 1386/2013/EU, 7th Environmental Action Plan, Recital 21.

7 Decision 1386/2013/EU, 7 th Environmental Action Plan. 
'coming under severe pressure' from the intense exploitation of economic opportunities within EU marine waters across diverse sectors, from fishing, shipping and aquaculture to mining, offshore energy generation and marine biotechnology. A decade ago, member states adopted legislation at the EU level with the intention of achieving good environmental status for their marine waters, which status could be measured according to objective criteria. ${ }^{8}$ Although the environment is an area of competence shared between the $\mathrm{EU}$ and its member states, the efficacy of environmental decisions adopted at the EU level relies on efficacious implementation by the member states. In practice, member states have been reluctant to curb commercial activities in marine areas, a resistance that is sought to be redressed through an integrated approach to management that will take account of all human activities within the area.

In 2007, the Commission published a Communication setting out its plan for an Integrated Maritime Policy (IMP). ${ }^{9}$ The IMP was proposed as a means of introducing a more coherent approach to the socio-economic demands placed on marine resources while, at the same time, ensuring environmental protection..$^{10}$ The Marine Strategy Framework Directive (MSFD) is the environmental arm of the IMP and was adopted with the intention of regulation taking account of all human activity in the marine environment so that these collective pressures will not overwhelm the capacity of ecosystems to support them. ${ }^{11}$ The MSFD is anticipated to support the Union's position on halting biodiversity loss. It is seen as augmenting the obligation of the member states to designate Natura 2000 sites to meet the biological diversity conservation and sustainable use objectives of the Convention on Biological Diversity (СвD). ${ }^{12}$

The MSFD recitals envisage the protection of the environment as being at the centre of all policy determination, with the individual sectoral policies coalescing around that objective. Its aim is to achieve good environmental status for EU waters by 2020 and it envisages an ecosystem-based management

8 Directive 2008/56/EC, Marine Strategy Framework Directive.

9 Communication from the Commission to the European Parliament, the Council, the European Economic and Social Committee and the Committee of the Regions - An Integrated Maritime Policy for the European Union, сом (2007) 575 final.

10 Ibid.

11 Report from the Commission to the Council and the European Parliament, 'Contribution of the Marine Strategy Framework Directive (2008/56/EC) to the implementation of existing obligations, commitments and initiatives of the member states or the EU at EU or international level in the sphere of environmental protection in marine waters', сом (2012) 662 final, paragraph 2.1; Directive 2008/56/EC, Marine Strategy Framework Directive, Article 1(3).

12 United Nations Convention on Biological Diversity (CBD) (Rio de Janeiro, 5 June 1992, 31 ILM (1992) 818), Article 8. 
approach that will apply the environmental protection principles of prevention, polluter-pays and, particularly, precaution..$^{13}$ The ecosystem-based approach is intended to ensure that human activities are kept to a level that is compatible with the achievement of good environmental status and do not compromise the ability of marine ecosystems to withstand human-induced changes while ensuring inter-generational equity. ${ }^{14}$

The problem with determining good environmental status is that once the environment is degraded it becomes difficult to gain agreement on what will constitute a good environmental status. Sustainability in fisheries used to occur 'where fish populations were naturally protected by having a large part of their distribution outside the range of fishing operations.' ${ }^{15}$ Pitcher argues that 'three ratchet-like processes have brought about episodes of depletion.'16 The first of these, 'Odum's ratchet', is ecological, comprising depletion and local extinction, which can be seen in the depletion of accessible fish stocks in waters close to the shores of coastal regions, causing more distant waters to be targeted for exploitation. ${ }^{17}$ The second phase, features 'Ludwig's ratchet', which is economic and is seen in increasing catching power and overinvestment causing serial depletion, driven by the need to repay capital investment. ${ }^{18}$ The final phase, 'Pauly's ratchet', is 'cognitive, shifting the baseline of what each generation regards as primal abundance and diversity'. ${ }^{19}$ This shifting baseline is significant for good environmental status because what constitutes ecologically diverse, productive seas becomes diminished with each degradation occasioned by human activity. The ecologically meaningful boundary that ecosystem-based management aims for, therefore, will be defined according to each current degraded status.

\footnotetext{
13 Directive 2008/56/EC, Marine Strategy Framework Directive, Recital 44.

14 Directive 2008/56/EC, Marine Strategy Framework Directive, Article 1(3).

15 D Pauly and others, 'Towards sustainability in world fisheries' (2002) 418 Nature 689.

16 T Pitcher, 'Fisheries Managed to Rebuild Ecosystems? Reconstructing the Past to Salvage the Future' (2001) 11 Ecological Applications 601.

17 Ibid. citing: W Gibbons and EP Odum, Keeping all the pieces: perspectives on natural history and the environment (Smithsonian Institution Press; Washington, DC: 1993).

18 Ibid., citing: D Ludwig, R Hilborn and C Walters, 'Uncertainty, resource exploitation and conservation: Lessons from history' (1993) 26o Science 36.

19 Ibid. citing: D Pauly, 'Anecdotes and the shifting baseline syndrome of fisheries' (1995) 10 Trends Ecol. Evol. 430.
} 
Many member states have been late in adopting implementing legislation and administrative provisions to comply with the MSFD, which had a deadline of July 2010. ${ }^{20}$ Even where member states have adopted legislation to implement the Directive, their progress towards establishing what would constitute good environmental status has been slow. Good environmental status is understood through a series of descriptors, ranging across eutrophication, pollution, seabed integrity, and the maintenance of sustainable levels of fish stocks among others, which together will ensure the ecological integrity and health of EU waters. ${ }^{21}$ For fish stocks, populations must be present and maintained within safe biological limits, exhibiting a population age and size distribution that is indicative of a healthy stock. While the MSFD describes the elements that go towards building environmentally sustainable seas, the Directive is not an instrument that can set out the means of achieving such status as the choice of form and methods to meet the stipulated requirements is left to the member states.

Under the terms of the Directive, each member state must assess the state of the marine environment within their own waters to identify current characteristics and environmental status. To ensure a coherent strategy to redress degradation, the MSFD establishes four marine regions. Within each region, each member state must develop strategies for its own waters and then, in conjunction with other member states in the same marine region, and in cooperation with other non-EU states having an interest in the area, agree the management of the area. This is to be done through development plans which will be devised taking account of the assessments of all the member states in the region. These plans are to define good environmental status for the area and enable clear environmental targets and monitoring programmes to be established. However, the Commission found that there has been no consistency between member states in their measuring the state of their waters. In an effort to progress the aim of good environmental status for EU waters, the EU has decided to replace the incoherence arising from diverse standards

\footnotetext{
20 Case C-245/12 Commission v Poland, OJ 2008 L164/9. Infringement action was taken by the Commission against Poland for failure to implement and a daily penalty of over $€ 93000$ was imposed by the Court.

Directive 2008/56/EC, Marine Strategy Framework Directive, Annex 1.
} 
and methods adopted by member states with new common threshold values. ${ }^{22}$ Some flexibility is provided as member states will be able to focus on the particular problems in their seas in reaching the threshold.

The new threshold values are expected to 'allow for an assessment of the quality level achieved for a particular criterion' on a uniform basis. These values are required to be consistent with Union legislation and, so that the standard translates into effective monitoring, must be set at appropriate geographic scales to reflect the different biotic and abiotic characteristics of the regions, subregions and subdivisions, where the basic regions are the Baltic, North East Atlantic, Mediterranean and Black Seas. The particular standard expected is to 'reflect natural ecosystem dynamics, including predator-prey relationships and hydrological and climatic variation, also acknowledging that the ecosystem or parts thereof may recover, if deteriorated, to a state that reflects prevailing physiographic, geographic, climatic and biological conditions, rather than return to a specific state of the past'. ${ }^{23}$ This last is an important concession to member states reluctant to interfere with commercial activities even though it is these commercial activities that have driven the deteriorating trend. Moreover, the standard conflicts with the fundamental objectives of the MSFD which require, so far as possible, the restoration of the marine environment. ${ }^{24}$ The IMP had envisaged the ecosystem-based approach delivering ecosystem resources 'for present and future generations. ${ }^{25}$ However, once a standard is accepted at a degraded level, the possibility of restoration or imposing responsibility for the damaged and diminished state of marine waters on those causing the degradation will be lost.

\section{$4 \quad$ The MSFD and Fisheries Policy}

According to the Treaty on the Functioning of the European Union (TFEU), the protection of the environment is to be integrated into all EU policies. ${ }^{26}$

22 Commission Decision (EU) 2017/848 of 17 May 2017 laying down criteria and methodological standards on good environmental status of marine waters and specifications and standardised methods for monitoring and assessment, and repealing Decision 2010/477/ EU (Text with EEA relevance), OJ $2017 \mathrm{~L} 125 / 43$.

23 Commission Decision (EU) 2017/848, Recital 13 and Article 4(1).

24 Directive 2008/56/EC, Marine Strategy Framework Directive, Recital 43, Article 1.

25 Communication from the Commission to the Council and the European Parliament The role of the CFP in implementing an ecosystem approach to marine management [SEC(2008) 449] COM (2008) 187 final.

26 Consolidated version of the Treaty on the Functioning of the European Union, [2012] OJ $\mathrm{C}_{326}$ (TFEU) Article 11. 
The MSFD requires the member states to take the measures necessary for the protection and preservation of the marine environment, including the prevention of deterioration and, 'where practicable', the restoration of marine ecosystems in areas adversely affected by human activity. ${ }^{27}$ Member states are to adopt marine strategies applying the ecosystem-based approach so that the collective pressures of human activity do not compromise the achievement of good environmental status or the ability of the marine environment to respond to human-induced changes. ${ }^{28}$ Fisheries policy with regard to resource exploitation is within the exclusive competence of the Union and imposes obligations on member states. The MSFD sets out objectives to be achieved but is unable to subject the CFP to its terms. Accordingly, the MSFD merely notes that the CFP should do no more than 'contribute to the protection of the marine environment' and achievement of good environmental status as set out in the MSFD. ${ }^{29}$ The Directive observes that the exclusive regulation of fisheries will continue under the CFP. ${ }^{30}$

Although fisheries policy is to be coherent with the Union environmental legislation, in particular with the objectives of achieving good environmental status by 2020', there is no requirement that the CFP either conforms to, or harmonises with, the environmental objectives of the MSFD and no specific terms to ensure coherence are set out. ${ }^{31}$ This means that the impact of the MSFD on fisheries policy is minimal. Some measures available for conservation under the Fisheries Regulation may be given wider application because of the MSFD. Closure of fisheries by reason of fish stock collapse provided under the CFP may be augmented so that closure may be ordered 'to enable the integrity, structure and functioning of ecosystems to be maintained or restored and, where appropriate, in order to safeguard, inter alia, spawning, nursery and feeding grounds. ${ }^{32}$ Nevertheless, neither the MSFD nor the Fisheries Regulation specifies further action with regard to fisheries policy to achieve good environmental status for the seas. The failure to integrate environmental and fisheries policy and to subject fisheries policy to environmental protection requirements operates to prevent regeneration and sustainability of both fish stocks and wider ecosystems.

27 Directive 2008/56/EC, Marine Strategy Framework Directive, Article 1(2).

28 Directive 2008/56/EC, Marine Strategy Framework Directive, Article 1(3).

29 Regulation 1380/2013, Recital 11.

$30 \quad$ Directive 2008/56/EC, Marine Strategy Framework Directive, Recital 39.

31 Regulation 1380/2013, Article 2(5)j.

32 Regulation 1380/2013, Article 8; Marine Strategy Framework Directive, Recital 39. 
The founding Treaty of Rome in 1957 established the European Economic Community and set out common policies. The Agricultural title of the Treaty, which includes fisheries, stipulates objectives for both sectors that have remained unchanged ever since..$^{33}$ No distinction is made between agriculture and fisheries despite agriculture being a husbandry industry while fishing is an extractive or mining activity, and there was and is no dedicated treatment for fisheries. According to the TFEU, both sectors are to increase productivity through technical progress and the optimum utilisation of labour, while ensuring a fair standard of living for those engaged in the sector, stabilising markets and securing the availability of supplies at reasonable prices for consumers. ${ }^{34}$ In 1970 , legislation was adopted so that within the 12 nautical mile $(\mathrm{nm})$ coastal waters, member states were required to regulate in accordance within single market rules adhering to the principles of nondiscrimination and proportionality. ${ }^{35}$ Beyond the $12 \mathrm{~nm}$ zone, member states had no independent decision-making powers with regard to fishing activity and member state waters were opened up giving equal access for fishing vessels registered in one member state to fish within the waters of any other member state. Externally, access to the waters of other states and agreements concerning fishing in international waters would be negotiated by the EU on behalf of the member states.

It was not until 1983 that the EU developed a fully formulated fisheries policy. ${ }^{36}$ Since then, the policy has been revised and updated in approximately decadal cycles. The current 2013 Fisheries Regulation notes that the EU is a contracting party to the UN Convention on the Law of the Sea (LOSC), the UN Fish Stocks Agreement (UNFSA), and the FAO Agreement to promote compliance with international conservation and management measures by fishing vessels on the high seas. ${ }^{37}$ Although the LosC implies an ecosystem based

\footnotetext{
33 Treaty establishing the European Economic Community, March 25, 1957, 298 UNTS 11.

34 Title III, Agriculture and Fisheries, Articles 39 TFEU.

35 Regulation (EEC) $2141 / 70$ of the Council of 20 October 1970 laying down a common structural policy for the fishing industry, [1970] OJ Spec Ed 703, repealed.

36 Council Regulation (EEC) 170/83 of 25 January 1983 establishing a Community system for the conservation and management of fishery resources, [1983] OJ L24/1, repealed.

37 Regulation 1380/2013, Recital 5: 1982 United Nations Convention on the Law of the Sea (LOSC) (Montego Bay, 10 December 1982, 1833 UnTs 3); United Nations Agreement for the Implementation of the Provisions of the United Nations Convention on the Law of the Sea 1982 relating to the Conservation and Management of Straddling Fish Stocks and Highly Migratory Fish Stocks (UNFSA) (New York, 4 December 1995, 2167 UNTS 3);
} 
management as a management mode, it was only in the subsequent UNFSA that the arrangements to be adopted for the regulation of straddling and highly migratory fish stocks were agreed, the terms of which signalled an ecosystembased management. Regulation is to encompass species other than targeted, commercially-exploited stocks and the UNFSA introduces an anticipatory approach to damage prevention through the precautionary approach. In application, states are to be 'more cautious when information is uncertain, unreliable or inadequate. The absence of adequate scientific information shall not be used as a reason for postponing or failing to take conservation and management measures.' ${ }^{38}$ Additionally, the interdependence of stocks is acknowledged so that stocks within the same ecosystem or associated with or dependent upon the target stocks, are to be managed and conserved to prevent any serious threat to their reproduction. ${ }^{39}$ The Fisheries Regulation observes that those agreements, essentially, are concerned with the obligation to regulate to maintain and restore fish resources at maximum sustainable yield (MSY), that is, the maximum volume of catches that can be taken each year without threatening the future reproductive capacity of a fish stock, through application of the precautionary approach. ${ }^{40}$

The precautionary approach is an international standard according to which 'the absence of adequate scientific information should not justify postponing or failing to take management measures to conserve target species, associated or dependent species and non-target species and their environment'. ${ }^{41}$ According to the Fisheries Regulation its aim is 'to ensure that exploitation of living marine biological resources restores and maintains populations of harvested species above levels which can produce Msy'.42 Although the precautionary approach is adopted from international law, under the terms of the CFP it is specifically stated to be derived from the precautionary principle as set out in the TFEU. ${ }^{43}$

UN Food and Agriculture Organisation, Code of Conduct for Responsible Fisheries (Code of Conduct), Rome, FAO. 1995. Article 7.5.1 and 2.

38 Article 6(2) UNFSA.

39 Article 5 (e) UNFSA.

40 Regulation 1380/2013, Recital 6 and Article 4(1)(7).

411995 United Nations Agreement for the Implementation of the Provisions of the United Nations Convention on the Law of the Sea 1982 relating to the Conservation and Management of Straddling Fish Stocks and Highly Migratory Fish Stocks (UNFSA) (New York, 4 December 1995, 2167 UnTS 3), Article 6(1) and (2); Regulation 1380/2013, Article 4(1)8.

42 Regulation 1380/2013, Article 2(2) and Article 4(1)(8).

43 Regulation 1380/2013, Recital 10 and Article 2(2); Article 191(2) TFEU. 
Whether the precautionary approach is a principle of international law is uncertain. Principle 15 of the Rio Declaration provides that, in order to protect the environment, the precautionary approach is to be widely applied. ${ }^{44}$ The UNFSA provides technical guidance for the approach in precautionary reference points that 'trigger pre-agreed conservation and management action'. 45 The adoption of the precautionary approach in international instruments may indicate it has become a customary rule of international law: 'General principles can become especially influential when like the precautionary approach they are adopted in a globally endorsed instrument such as the 1992 Rio Declaration on Environment and Development:46 As such, the precautionary approach may exert 'a general influence (...) on the interpretation, application, and development of other rules of law' ${ }^{47}$ However, there is little evidence of a risk situation generating the use of a precautionary approach to restrict fishing activity. Its use was widely discussed following the Southern Bluefin Tuna cases. In those cases, the evidence was that continuing tuna exploitation would pose a serious risk to tuna conservation, so interim measures to prevent fishing were granted pending the full hearing of the dispute. On one account, the granting of interim measures revealed 'a classic precautionary approach' 48 Transferring the burden of proof to the defendant to show harm would not ensue if fishing were to continue could be seen as precautionary. An alternative explanation of the ruling is that the nature of provisional measures, granting temporary injunctive relief pending full investigation in the main hearing, necessitates a precautionary approach by the judicial authority. ${ }^{49}$ On this interpretation

44 Rio Declaration on Environment and Development (Rio Declaration) (Rio de Janeiro, 14 June 1992, UN Doc. A/CONF.152/26 (vol. 1) reprinted in 31 ILM 874 (1992), Article 15: 'In order to protect the environment, the precautionary approach shall be widely applied by States according to their capabilities. Where there are threats of serious or irreversible damage, lack of full scientific certainty shall not be used as a reason for postponing cost-effective measures to prevent environmental degradation.' The Food and Agriculture Organisation of the United Nations, 1995 Code of Conduct for Responsible Fisheries adopts the precautionary approach reiterating the Rio Declaration that fisheries management organisations should apply a precautionary approach widely to the conservation, management and exploitation of living aquatic resources.

45 UNFSA Annex II, paragraph 4.

46 A Boyle, "The Environmental Jurisprudence of the International Tribunal for the Law of the Sea' (2007) 22 Int'l J. Marine \& Coastal L. 369, 374-375.

47 Ibid.

48 Southern Bluefin Tuna Cases (New Zealand v Japan; Australia v Japan) (Provisional Measures) (1999) 38 ILM 1624; T Stephens, International Courts and Environmental Protection (Cambridge University Press, Cambridge, 2009) 225.

49 P Birnie, A Boyle and C Redgwell, International Law and the Environment (Oxford University Press, Oxford, 2008) 16o, citing: New Zealand v Japan; Australia v Japan (Provisional 
no substantive decision was made in exercise of the precautionary approach. In the event, when the dispute came to full hearing, the ban was not upheld. ${ }^{50}$

Under the Fisheries Regulation, the precautionary approach is to be based on the legally-binding precautionary principle. ${ }^{51}$ The precautionary principle was incorporated into EU law in the environmental chapter of the Maastricht Treaty in $1993 .{ }^{52}$ At the same time, the Treaty introduced an obligation requiring environmental protection to be integrated into the definition and implementation of all EU policies. ${ }^{53}$ The Commission was tasked with providing explication of the principle and described its scope as being applicable where 'there are reasonable grounds for concern that the potentially dangerous effects on the environment, human, animal or plant health may be inconsistent with the high level of protection chosen for the Community'.54 The precautionary principle has been raised only once in a case concerning the CFP that was brought before the Court of Justice. ${ }^{55}$ In that case, the Court was careful to refer to the precautionary approach with the implication that the precautionary principle is not applicable to fishing activity. Through its case law, the Court of Justice has restricted the application of the precautionary principle to matters concerned with human health and consumer safety across all EU activity. The Court has not extended it to the protection of the environment unless human health is directly at risk. ${ }^{56}$

While there is no doubt that degraded fish stocks and marine environments have enormous adverse implications for human welfare, the proximate relationship the Court identifies as necessary to require the adoption of the precautionary principle is absent. As the risk posed by overfishing is not to human health, the exclusion of risk has not informed practice under the CFP. Indeed, it has been argued that risk to stocks is optimised to exclude 'arbitrary

measures) (1999) 38 ILM 1624, Judge Tulio Treves, paragraph 9 and Judges Shearer and Laing, paragraphs 16-19.

5o Southern Bluefin Tuna Cases (Australia and New Zealand v Japan), Award on Jurisdiction and Admissibility (2000) 39 ILM 1359.

51 Regulation 1380/2013, Recital 10.

$5^{2}$ Treaty on European Union (Consolidated Version), (Treaty of Maastricht), OJ 1992 $\mathrm{C}_{325} / 5$.

53 Now, Article 11 TFEU.

54 Communication from the Commission on the precautionary principle, Сом (2000) 1 final, 3 .

55 Case C-453/08 Karanikolas and Others [2010] ECR I-7895.

56 Joined Cases T-74, 76, 83-85, 132, 137, 141/oo, Artegodan GmbH and Others $v$ Commission [2002] ECR II-4945, paragraph 183; Case C-453/o8 Karanikolas and Others [2010] ECR $\mathrm{I}-7895$. 
safety margins. ${ }^{57}$ Most fish stocks have been exploited in excess of their MsY at the margin of biological sustainability. Not infrequently, permissible catch levels are set beyond MSY as advised by scientists so imperilling stock regeneration. An analysis of total allowable catches set for eleven fish stocks between 1987 and 2011 found that $68 \%$ had been set in excess of MSY scientific advice, averaging catches $33 \%$ over recommendation. ${ }^{58}$ European states continue to press for extraction in excess of scientific advice. For example, the EU and Norway went to great lengths to persuade ICES to increase its recommendation for the maximum extraction of cod from the North Sea and revise its assessment of a precautionary quantity. When the 2014 extraction tonnages were agreed, an increase of $5 \%$ had been secured but the effort restrictions that ICEs had stipulated would have to be imposed to render the quantity precautionary were not notified by participating states. ${ }^{59}$

The CFP and the Ecosystem Approach

The ecosystem-based approach has a role in the CFP but it is marginal. In the context of ongoing concern about the sustainability of fish stocks and the need to put the sector onto a more viable footing, the Fisheries Regulation stipulates that 'the CFP shall implement the ecosystem-based approach' to minimise the adverse effects of marine fishing on the marine environment and avoid its degradation, and in particular should contribute to the achievement of good environmental status for marine areas by $2020 .{ }^{60}$ The approach is defined as meaning: 'an integrated approach to managing fisheries within ecologically meaningful boundaries which seeks to manage the use of natural resources, taking account of fishing and other human activities, while preserving both the biological wealth and the biological processes necessary to safeguard the composition, structure and functioning of the habitats of the ecosystem affected, by taking into account the knowledge and uncertainties regarding biotic,

57 E Fenichel and others, 'Real Options for Precautionary Fisheries Management' (2008) Fish and Fisheries 121, 121-122.

$5^{8}$ BC O'Leary and others, 'Fisheries Mismanagement' (2011) 62 Marine Pollution Bulletin 2642.

59 ICES, Special Request, EU-Norway request to ICES on increasing the 2014 TAC for cod in the North Sea - Additional reply to part of the original request, Advice March 2014, 6.2.3.2: $<$ www.ices.dk/sites/pub/Publication\%2oReports/Advice/2014/Special\%2oRequests/EU_ Norway_2014_TAC_for_NS_cod_March.pdf > accessed 20/11/2017.

6o Regulation 1380/2013, Article 2(5)(j). 
abiotic and human components of ecosystems.61 As such, the approach is highly complex involving variables and diffuse ecological and socio-economic objectives, but how a balancing between them is to be struck is not elaborated. However, there are few circumstances in which this holistic approach is to be adopted, although it may be used to address the specific problems of mixed stock fisheries where selectivity cannot be achieved. ${ }^{62}$

By reference to the MSFD, the Fisheries Regulation observes that member states are empowered to adopt conservation measures within waters under their jurisdiction in order to comply with their obligations under EU environmental law. There is a caveat, though, in that any environmental protections adopted must not affect the fishing vessels of other member states and must be compatible with CFP objectives. ${ }^{63}$ Compatibility with the CFP makes it almost impossible for a member state to act unilaterally to adopt measures for environmental protection in their marine areas because of the impact on fishing operations. The only exception is in case of emergency where there is a serious threat to marine biological resources or the ecosystem. In such situations, the member state is required to consult with the Commission and member states who will be affected by the restriction as well as relevant fisheries Advisory Councils before a measure is adopted. Even where the member state adopts an emergency measure, the Commission may intervene to countermand the measure and require the member state to repeal it. ${ }^{64}$

Although the member states have few powers to act against damaging fishing activity, the Commission may adopt restrictive measures for environmental protection that will apply to all vessels. ${ }^{65}$ But again, the interruption of fishing activity is made exceptional so that restrictions are to be temporary and for no more than six months, renewable once. ${ }^{66}$ The right to fish is so well entrenched under the terms of the Treaty that secondary measures to displace fishing activity will be possible only on agreement between all affected member states rendering the protection of the environment very difficult to achieve. The CFP gives priority to economic activity over environmental concerns, so to try to facilitate better protections there has been a devolution of conservation powers under the CFP as part of the governance reform.

\footnotetext{
61 Regulation 1380/2013, Article 4(9).

62 Regulation 1380/2013, Article 9(5).

63 Regulation $1380 / 2013$, Article $11(1)$.

64 Regulation 1380/2013, Article 13.

65 Regulation 1380/2013, Article 11(2).

66 Regulation 1380/2013, Article 12-13.
} 
The 2013 Fisheries Regulation included an overhaul of governance to allow member states greater opportunity to act towards meeting the environmental objective of good environmental status within the context of the CFP. ${ }^{67}$ Regions are grouped according to sea basin, and member states within a region having a direct interest in a fishery may, by consensus, submit a proposal for a conservation measure which may be adopted by the Commission in a delegated or implementing act. ${ }^{68}$ These measures enable the Commission to amend or supplement non-essential aspects of CFP legislation, including environmental measures. The Commission may adopt a measure to give effect to the joint recommendation but only if compatible with the relevant fishery conservation measure or multiannual plan. ${ }^{69}$ However, the Commission act may be revoked at any time by either the European Parliament or the Council. The Commission powers may be used with regard to: conservation measures within a geographical region; multiannual plans, under which all fishing is to be managed in the future; and discard plans. Discarding unwanted catch is being phased out under the Fisheries Regulation which sets out stocks that are subject to the landing obligation. The reach of the discard ban, which is seen as the major innovation for conservation under the Fisheries Regulation, may be augmented by intervention from the member states, again in a joint recommendation. Where member states in a particular region or subregion are able to reach unanimous agreement on species not specified in the Regulation, member states may recommend the institution of a landing obligation. ${ }^{70}$

Cooperation between member states within a region to formulate joint recommendations for environmental protection to comply with environmental law obligations is mandatory. ${ }^{71}$ Although member states have powers to establish conservation measures, to date, there has been only limited action to do so. The Dogger Bank Site of Community Importance, a designation which signifies that the area is essential to the long-term survival of some of Europe's most threatened species and habitats, has been established following agreement between Germany, the Netherlands and the UK in the North Sea. Despite its designation as a part of the Natura 2000 network, the UK is developing wind farms within the area and the Dutch government resisted the prohibition on

67 Regulation 1380/2013, Title III.

68 Regulation $1380 / 2013$, Article 46.

69 Regulation 1380/2013, Article 18.

70 Regulation 1380/2013, Article 15(3).

71 Regulation 1380/2013, Article 18. 
bottom trawl gear on the ground that this would be too costly for its fishing industry. ${ }^{72}$

Within these new regional structures, the ability of the fishing industry to resist environmental protections which they perceive not to be in their interests should not be underestimated. With the emphasis on participatory democracy, the fisheries Advisory Councils are categorised as stakeholder bodies whose 'appropriate involvement' is to be ensured at all stages in the passage of measures 'from conception to implementation. ${ }^{73}$ Their powers have been increased from those enjoyed by their predecessor Regional Advisory Councils and now no measures affecting fishing activity may be adopted without reference to the Advisory Councils. Although the opinions of the Advisory Councils are not binding they have been given substantial weight. Where the final measure adopted diverges from the opinions, recommendations or suggestions received from the Advisory Councils, the Commission or member state adopting the measure must give detailed reasons to explain the divergence. ${ }^{74}$

Despite regulatory structures having long been identified as susceptible to domination by the economic interests they have been designated to control, ${ }^{75}$ the issue of regulatory capture is not recognised within the CFP. Better governance and greater democracy have been an objective of the Commission since turn of the millennium. Democracy could be enhanced by increasing stakeholder participation, and this became one of the platforms of the 2013 CFP reform. ${ }^{76}$ Within the Advisory Councils, $60 \%$ of the seats are to be allocated to the fishing industry, including organisations representing the fisheries, processing and marketing sectors. With a structural majority the industry is free to pursue its own agendas, and is assured a decisive voice in drawing up management recommendations. The remainder of the seats on the Advisory Council are to be shared between disparate interest groups, such as women, environmental and consumer groups. ${ }^{77}$ Consulting on the 2013 fishery reforms, the Commission sought the views of the North Sea Regional Advisory Council (NSRAC) on its role in devising fisheries policy. NSRAC expressed

72 S Hommes and others, Report on cross-border Maritime Spatial Planning in two case studies, MASPNOSE 2012, 46 and 52, <www.wur.nl/upload_mm/7/6/2/92fbfd 4 c-5bo1 -4e8e-9a82-de877fa6d515_MASPNOSE\%2oD1.2\%20MSP\%2oin\%2ocase\%2ostudies.pdf> accessed 20/11/2017.

73 Regulation 1380/2013, Article 3(f).

74 Regulation 1380/2013, Article 44(4).

75 P Sabatier, 'Social Movements and Regulatory Agencies: Towards a More Adequate - and Less Pessimistic - Theory of Clientielle-Capture' (1975) 6 Policy Sciences 301.

76 European Commission, Green Paper on the Reform of the Common Fisheries Policy сом (2009) 163 .

Regulation 1380/2013, Article 45(1) and Annex III(2). 
satisfaction with current arrangements and reported it had 'not felt any supervision from the Commission' but welcomed the Commission's contribution'78 Although the Commission had raised concerns about the lack of representation for the small-scale fleet in NSRAC, NSRAC dismissed the issue, suggesting the Commission itself institute outreach initiatives to connect with small-scale operators. ${ }^{79}$ Meanwhile, the European Parliament called for one half of the seats on the Advisory Councils to be reserved for interested parties outside the fishing industry, but this was not accepted by the member states in Council. ${ }^{80}$ This stakeholder participation is a flawed democratisation already criticised for leading to insufficiently inclusive institutions. ${ }^{81}$ It is a textbook example of regulatory capture whereby a smaller group with a cohesive voice is able to triumph over the disparate views of the majority. The new governance model gives predominance to the strongest interest group, comprising the fishing and fish processing industries. There is little prospect of intervention to promote the sustainability of the resource as the largest interest group, the general public, has no effective representation.

Marine Protected Areas

With a view to restoration to MSY and 'in order to contribute to the conservation of living aquatic resources and marine ecosystems', the Fisheries Regulation provides for the establishment of fish stock recovery areas for areas of biological sensitivity. ${ }^{82}$ Member states will generally be required to recommend these areas to the Commission with the intention of building a coherent network of protected sites. Nevertheless, despite reference to ecosystem conservation, stock recovery areas under the Fisheries Regulation fall short of the ecosystem protection areas sought under the MSFD. The MSFD outlines specific programmes of protection that must include spatial protection measures that will contribute 'to coherent and representative networks

78 North Sea Regional Advisory Council, Response from the North Sea Regional Advisory Council - Consultation on Future Role and Composition of Advisory Councils, Position Paper $3(2012 / 13)$.

79 Ibid., paragraph 3.4 .

8o U Rodust, Draft Report on the proposal for a regulation of the European Parliament and of the Council on the Common Fisheries Policy, 2011/0195 (COD).

81 M Dreyer and P Sellke, 'The Regional Advisory Councils in European Fisheries: An Appropriate Approach to Stakeholder Involvement in an EU Integrated Marine Governance?' in M Gilek and K Kern (eds), Governing Europe's Marine Environment: Europeanization of Regional Seas or Regionalization of EU Policies? (Routledge, Abingdon, 2015) 121-140.

82 Regulation 1380/2013, Recital 22 and Article 8. 
of marine protected areas, adequately covering the diversity of the constituent ecosystem. ${ }^{83}$ The intention was to build on measures already adopted in order to protect wildlife and habitats. The Birds Directive requires member states to establish Special Protection Areas, and the Habitats Directive requires Special Areas of Conservation for other species and habitats. ${ }^{84}$ Neither the special areas of conservation for endangered species, flora and fauna pursuant to the Habitats Directive, nor the special protection areas established pursuant to the Birds Directive, are particularly suited to the protection of marine habitats, both being more appropriate for terrestrial protection. Nevertheless, the MSFD provides for the possible establishment of marine protected areas to complement areas protected under the Birds and Habitats directives, and such areas may acquire specific use designation as protected areas. ${ }^{85}$ Marine protected areas (MPAs) may be agreed either by the EU or by member states in international or regional agreement in order to build the Natura 2000 network, and the MSFD makes their establishment mandatory, particularly in achieving good environmental status for marine areas.

The ospar Convention for the Protection of the Marine Environment of the North East Atlantic, covers all human activities in the marine area except fishing and has fifteen participating governments, including all the EU member states bordering the North East Atlantic, Luxembourg, Iceland, Norway and Switzerland. ${ }^{86}$ The EU cooperates with the OSPAR Commission and member states coordinate their actions for marine protection as required under the MSFD through OSPAR mechanisms and structures. ${ }^{87}$ In 2015 the EU's Environmental Agency (EEA) published a report on MPAs in EU waters showing the

83 Directive 2008/56/EC, Marine Strategy Framework Directive, Article 13(4).

84 Directive 2008/56/EC, Marine Strategy Framework Directive, Article 13(4); Council Directive 92/43/EEC of 21 May 1992 on the conservation of natural habitats and of wild fauna and flora [1992] OJ L206/7 (Habitats Directive); Directive 2009/147/EC of the European Parliament and of the Council of 30 November 2009 on the conservation of wild birds [2010] OJ L20/7 (Birds Directive).

85 Directive 2008/56/EC, Marine Strategy Framework Directive, Article 13(4); Directive 2014/89/EU of the European Parliament and of the Council establishing a framework for maritime spatial planning [2014] OJ L257/135, Article 8, specifies 'nature and species conservation sites and protected areas' as possible use designations.

861992 Convention for the Protection of the Marine Environment of the North-East Atlantic (OSPAR) (Paris, 22 September 1992, 2354 UnTS 67).

87 OSPAR Commission, Finding Common Ground: Towards regional coherence in implementing the Marine Strategy Framework Directive in the North East Atlantic region through the work of the OSPAR Commission; OSPAR Commission, OSPAR Regional Implementation Framework for the EU Marine Strategy Framework Directive: MSFD Road Map, <www.ospar.org/work-areas/cross-cutting-issues/msfd/ospar-msfd > accessed 20/11/2017. 
proportion of EU waters protected in MPAs. At the end of 2012 they covered $4.2 \%$ of the North East Atlantic Ocean, including the Icelandic, Norwegian and Barents seas. ${ }^{88}$ Whilst this might suggest that progress is being made towards greater protection of marine areas, many of the MPAs overlap sites designated under the OSPAR Convention so that the impact of the MSFD may be rather minor.

Across the EU, by 2013 only six out of 22 member states had met the Natura 2000 requirements in terms of site designations for all relevant marine habitat types, and only four had met requirements for all relevant marine species. ${ }^{89}$ Merely listing protected areas is not enough to secure their protection; such areas need to be controlled and maintained. With regard to habitats, assessments are required for each of those listed under the Habitats Directive which are then classified as favourable or unfavourable, the latter being further broken down into inadequate or bad. In the North East Atlantic for the period 2007 to $2012,71.4 \%$ of all sites habitats were reported as being in a bad state, while the status of the remaining proportion was simply unknown. ${ }^{90}$ The EEA attributed the failure to establish a comprehensive Natura network to the absence of a supportive legal framework. Pursuant to existing legislation, over one thousand marine habitats have been identified but only nine are covered by the Natura protection scheme and these deal, in the main, with coastal sites. ${ }^{91} \mathrm{Few}$ species have been listed for protection, even though the EEA report notes that over 36,000 , excluding bacteria, have been identified. ${ }^{92}$ Furthermore, protection has been sought for discrete habitats and species without any recognition that the favourable conservation status sought by the legislation can only be achieved in the context of healthy resilient seas, and these will not emerge until an ecosystem-based management is adopted. 'Gaps still exist in terms of representativeness, coherence, adequacy and management effectiveness. ${ }^{93} \mathrm{In}$ general, Natura 2000 sites are not closed to commercial fisheries and very few sites appear to be no extraction sites.

88 J Reker and others, European Environmental Agency, 'Marine protected areas in Europe's seas: An overview and perspectives for the future' E EA Report, No 3/2015 (European Environmental Agency 2015).

89 Ibid., 15 .

$90 \quad$ Ibid., 16.

91 Ibid., 17, citing CE Davies and others, 'EUNIS Habitat Classification Revised 2004', (http:// eunis.eea. europa.eu/upload/EUNIS_2004_report.pdf) accessed 6 March 2014.

92 Ibid., 17, citing MJ Costello and SP Wilson, 'Predicting the number of known and unknown species in European seas using rates of description: Predicting species diversity', (2011) 20 Global Ecology and Biogeography 319. 
In so far as the CFP is focused on restricting fish extraction to prevent overfishing, its purpose is to enable stocks to be restored to MSY while permitting extractive activity to continue. Although the CFP is expected to contribute to the environmental objective of good environmental status for the seas, the few tools available to regulators are under-utilised. A recent study of fisheries management argued for the establishment of marine protected areas as being efficacious to satisfy both fishery and biodiversity conservation objectives. ${ }^{94}$ The authors contend such areas should be established as no-take zones because they have demonstrable benefits for conservation in their ability to foster resilient ecosystems and seed the external areas. MPAs are observed to 'preserve biological diversity at regional scale, at all levels - specific, habitat/ seascape, and also genetic diversity and the structure of populations, allowing natural selection to operate'. Furthermore, 'they maintain the natural size and age structure of the populations, hence maximizing potential fecundity, allowing biomass export to occur from core to regulated areas, dampening the fluctuations derived from deviations from the theoretical optimal effort in the fishing zone. ${ }^{95}$

The benefits of securing areas for regeneration and the conservation of biodiversity are acknowledged to be aims worth pursuing but there is resistance to the establishment of MPAs in the North East Atlantic. This is evident from another branch of management that also seeks a more coherent and cohesive policy governing EU seas. The Integrated Maritime Spatial Planning Directive (MSP) is predicated on an evaluation of the cumulative effect of human activities in marine areas and the application of the precautionary principle has been adopted as the management mode for EU waters. ${ }^{96}$ The intention is to avoid conflicts in use, identify the impact of human activities in marine areas and thereby facilitate multiple use. Although MSP aims for the sustainable growth of marine economies and the sustainable use of marine resources, the aspirational nature of the provisions of the directive governing the area is evident in that planning by the member states is to do no more than 'aim to contribute' to the outcomes specified. An ecosystem-based approach in planning, taking account of economic, social and environmental aspects and support sustainable growth and development is sought. ${ }^{97}$ However, a hierarchy of immediate

94 A Pérez-Ruzafa, J Garcia-Charton and C Marcos, 'North East Atlantic vs. Mediterranean Marine Protected Areas as Fisheries Management Tool', Frontiers of Marine Science, 3 August 2017, <https://doi.org/10.3389/fmars.2017.00245 > accessed 20/11/2017. Ibid.

96 Directive 2014/89/EU of the European Parliament and of the Council establishing a framework for maritime spatial planning [2014] OJ L257/135. 
concerns is set out in the directive. The ecosystem-based approach is to be applied: first, to the development of the energy sector; second, to maritime transport; third, to fisheries and aquaculture, and, finally, to the protection and improvement of the environment, including resilience to climate change. ${ }^{98}$ In all this, the prioritisation of biodiversity and ecosystem protection seems to have been overlooked and, in practice, the ultimate aim appears to be to incorporate other commercial activities into already stressed fishing areas. ${ }^{99}$

The Dogger Bank Special Area of Conservation (SAC) is currently classed as in unfavourable conservation status with Germany, which is particularly concerned to restore typical and threatened species, advocating the banning of trawling in order to meet commitments under the Habitats Directive. ${ }^{100}$ This was resisted by the UK and Netherlands but, eventually, they agreed six management zones, comprising one third of the total area, in which bottom trawl and dredges are banned. Measures adopted are justified as making a key contribution to conservation objectives, 'while, as far as possible, minimizing impacts on the fishing industry'.101 Meanwhile, in furtherance of the MSP agenda, the UK section of the Site of Community Importance (SCI) is to be developed for green energy production, a project opposed by nature conservation groups. The harbour porpoise, a cetacean (phocoena phocoena), listed in the IUCN red list of threatened species and listed in the Habitats Directive as a species of Community interest requiring strict protection in their natural range, is resident in high density, year-round in the Dogger Bank area. ${ }^{102}$ Protection for the porpoise under the Habitats Directive includes a prohibition on 'the deliberate disturbance' of the species and the 'deterioration or destruction of breeding sites or resting places'.103 Scientific evidence is that windfarm construction, including acoustic disturbance from pile driving, will affect harbour

\section{Directive 2014/89/EU, Article 5(2).}

99 Displace, spatial model of fisheries to help maritime spatial planning, <www.msp -platform.eu/node/85> accessed 22/11/2017.

100 Background Document to the draft Joint Recommendation for Offshore Fisheries Management on the International Dogger Bank under the revised Common Fisheries Policy, The Hague, Bonn, London, 31 May 2016, <http://lbst.dk/fileadmin/user_upload/Natur Erhverv/Filer/Fiskeri/Natura_200o_hav/Fiskeriregulering_i_andre_lande/20160531_ Dogger_Bank_Background_Document_final.pdf $>$ accessed 23/11/2017.

101 Ibid., paragraph 7(4)(10).

102 Directive 92/43/EEC, Annex IV(a); The IUCN Red List of Threatened Species, <www .iucnredlist.org/details/17027/0> accessed 20/11/17; A-C Cucknell and others, 'Harbour porpoise (Phocoena phocoena) presence, abundance and distribution over the Dogger Bank, North Sea, in winter' (2017) 7 Journal of the Marine Biological Association of the UK, 1455 .

103 Directive 92/43/EEC, Article 12 and $\operatorname{Annex~IV(a).~}$ 
porpoises leading to physical damage, altered metabolisms and behavioural changes, hampering population recruitment. ${ }^{104}$ In 2016, the Commission commenced action against the UK for its breach of the Habitats Directive in failing to designate sites for the protection of harbour porpoise in proportion to the species' representation within UK territory to contribute to the creation of a Natura 2000 network. ${ }^{105}$ This case is yet to be heard but, even if successful, the Dogger Bank development will probably be unaffected as the Habitats Directive allows derogation in the public interest for economic or social reasons. ${ }^{106}$ While sustainable development demands that the three conflicting interests of economic, social and environmental protection are to be taken into account, ecosystem-based management in marine spatial planning appears to be largely calibrated towards economic development.

\section{$9 \quad$ State Aid for Exploitation}

Since its inception, the CFP has been beset by problems of overinvestment resulting in overcapacity and overfishing. The total catch of the EU fishing fleet has fallen almost every year since its high in 1995, so that by 2012 it was $28 \%$ lower than in 2001 and $42 \%$ lower than in $1995 .{ }^{107}$ Eurostat reports that latest production figures for 2014 'suggest' a rise in total marine fish catch, but it is not clear how this compares with earlier years. ${ }^{108}$ Successive fisheries regulations have sought to address the issue of overexploitation by reducing fleet capacity. As a matter of resource conservation, ${ }^{109}$ action is required to ensure member state fishing fleets are adjusted to a level consonant with the fishing opportunities available to them, resulting in 'economically viable fleets without overexploiting marine biological resources' ${ }^{110}$ It is incumbent on the member states

104 C Peng, X Zhao and G Liu, 'Noise in the Sea and Its Impacts on Marine Organisms' (2015) 12 International Journal of Environmental Research and Public Health 12304.

105 Case C-669/16 European Commission v UK, not yet heard; Directive 92/43/EEC, Article 4(1) and Annexes II and III.

106 Directive 92/43/EEC, Article 16(1)(c).

107 Eurostat, Facts and Figures on the CFP (Luxembourg, 2008) 16; Eurostat, Fishery Statistics, Data from May 2014, <http://epp.eurostat.ec.europa.eu/statistics_explained/index.php/ Fishery_statistics $>$ accessed 20/11/2017.

108 Eurostat, Agriculture, forestry and fishery statistics, 2016 edition, 192, <http://ec.europa .eu/eurostat/documents/3217494/7777899/KS-FK-16-oo1-EN-N.pdf/cae3c56f-53е2-404a -gege-fb5f57ab49e3> accessed 20/11/2017.

109 Regulation 1380/2013, Article 7(c).

110 Regulation 1380/2013, Article 2(5)(d). 
themselves to align the number of vessels in their fleet with resources available to them, however, a latitude is provided in that this is to be done 'over time.'111

Despite efforts to redress overcapacity, overinvestment in the marine fisheries sector is facilitated by the financial supports provided to the fishing industry and exemptions from the general rules on state aid and competition set out in the Treaty. Deviating from the general approach to anti-competitive practices, the TFEU provides that rules on competition are to apply to agriculture and fisheries only to the extent determined by the European Parliament and Council. Specifically, aid may be authorised to 'enterprises handicapped by structural or natural conditions' or within economic development

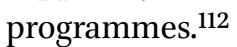

Because of the protected status of agriculture and fisheries under the Treaty, aid is provided by EU law, ostensibly for purposes of increasing production, ensuring a fair standard of living for workers, stabilising markets, ensuring the availability of supplies, and keeping costs down for consumers. ${ }^{113}$ An OECD study of the obstacles to the removal of harmful subsidies noted that, despite the Lisbon Agenda for competitiveness and job creation, there was no sign of the EU undertaking fishery subsidy reforms that would contribute to those objectives 'any more than the environmental commitments'. ${ }^{114}$ A subsequent investigation into the effect of EU fishery subsidies found that capacity enhancing projects that reduce the costs of the industry received five times the amount of subsidy made available for schemes that would enhance the growth of fish stocks through conservation. ${ }^{115}$

In 2014, a new instrument dealing with de minimis aid to the fishing industry was adopted, permitting aid up to the value of $€_{30,000}$ per recipient over the course of three years. ${ }^{116} \mathrm{~A}$ new block exemption for fisheries and aquaculture has been adopted which applies to 'aid granted to small and medium-sized enterprises (SMEs) active in the production, processing or marketing of fishery

\footnotetext{
111 Regulation 1380/2013, Articles 22.

112 Article 42 TFEU.

113 Title III, Agriculture and Fisheries, Articles 39-40 TFEu.

114 J Brown, 'Fisheries' in OeCD, Subsidy Reform and Sustainable Development (oecD 2007) $111-119$.

115 U Rashid Sumaila and others, Global Fisheries Subsidies, October 2013, IP/B/PECH/2013146, 24, <www.europarl.europa.eu/RegData/etudes/note/join/2013/513978/IPOL-PECH_ NT(2013)513978_EN.pdf > accessed 20/11/2017.

116 Commission Regulation 717/2014 on the application of Articles 107 and 108 of the Treaty on the Functioning of the European Union to de minimis aid in the fishery and aquaculture sector OJ $2014 \mathrm{~L} 190 / 45$.
} 
and aquaculture products.'17 Aid covered by the exemption which does not have to be notified to the Commission includes aid for: innovation, advisory services, partnerships between scientists and fishermen, job creation, health and safety, mitigation of climate change, and administrative systems. ${ }^{118} \mathrm{Com}-$ pliance with protective measures is amenable to financial support compensating for losses of unfettered access to fishing areas or stocks. The unwanted catches that previously have been discarded but which are now subject to a progressive timetable requiring they be landed, ${ }^{119}$ may attract aid. ${ }^{120}$ Most surprisingly, the terrestrial infrastructure of fishing, that is the financing of ports, landing sites, auction halls and shelters, all attract aid. ${ }^{121}$ Further aid is available to meet the environmental objectives of mitigating the damage caused by fishing activity. ${ }^{122}$

As well as subsidies from the member states, the fisheries sector is entitled to aid from the Union through the EU's Structural and Investment programmes. The European Maritime and Fisheries Fund (EMFF) seeks to promote the Europe 2020 project for a smart, sustainable and inclusive economy with the emphasis on jobs and innovation. ${ }^{123}$ The EMFF is to promote the objectives of fisheries policy and contribute to the implementation of the CFP so that there is a prohibition on funding that will increase capacity. ${ }^{124}$ Funding available mirrors many of the areas covered by the block exemption permitting state aid for the sector. However, the EMFF also provides funding for the 'the enhancement of the competitiveness and viability of fisheries enterprises', which can include support for failing entities. ${ }^{125}$

117 Commission Regulation (EU) No 1388/2014 of 16 December 2014 declaring certain categories of aid to undertakings active in the production, processing and marketing of fishery and aquaculture products compatible with the internal market in application of Articles 107 and 108 of the Treaty on the Functioning of the European Union OJ 2014 L369/37.

118 Commission Regulation (EU) No 1388/2014, Articles 13-22.

119 Regulation 1380/2013, Article 15(1).

120 Regulation 1388/2014 Article 27.

121 Commission Regulation (EU) No 1388/2014, Article 28.

122 Commission Regulation (EU) No 1388/2014, Articles 23-26.

123 Regulation (EU) No 508/2014 of the European Parliament and of the Council on the European Maritime and Fisheries Fund and repealing Council Regulations (EC) No 2328/ 2003, (EC) No 861/2006, (EC) No 1198/2006 and (EC) No 791/2007 and Regulation (EU) No 1255/2011 of the European Parliament and of the Council [2014] OJ L149/1 (Maritime and Fisheries Fund Regulation).

124 Regulation (EU) No 508/2014, Article 5.

125 Regulation (EU) No 508/2014, Article 6(1)(d). 
Emerging out of the European Union's IMP, the EU developed its Blue Growth agenda, described by the Commission as intending the harnessing of 'the untapped potential of Europe's oceans, seas and coasts for jobs and growth.' 126 The 'core objective' of the agenda is described as being 'to exploit the potential of the seas and oceans in order to make a significant and sustainable contribution to economic growth, by creating new jobs while better respecting natural resources and the marine environment'.127 Aquaculture, coastal tourism, marine biotechnology, ocean energy, and seabed mining are identified as offering growth and jobs potential, while the most basic of marine activities, marine fishing, is identified as an industry in decline along with the carbon-based energy sector and, as a consequence, has been excluded. ${ }^{128}$ However, since this exclusion, the reforms in the CFP seem to have been highly beneficial for the fish-catching sector. In its 2016 Staff Working Document on Blue Growth Strategy, the Commission refers to 'parallel' developments with regard to the new, reformed CFP. ${ }^{129}$ The traditional European fisheries sector is reported as having improved economic and social sustainability as a result of the reforms to the CFP, so that the EU fleet 'has moved from a loss-making position in 2008 to high profitability today'.130 Huge profits are available to a relatively small number of operators, generating just over 110,000 full-time jobs, jobs that are seen to be low-skilled and low-paid. ${ }^{131}$

126 Communication from the Commission to the European Parliament, the Council, The European Economic and Social Committee and the Committee of the Regions, Blue Growth Opportunities for Marine and Maritime Sustainable Growth, сом (2012) 494 final, 2 .

127 Ibid., 5 .

128 Communication from the Commission to the European Parliament, the Council, The European Economic and Social Committee and the Committee of the Regions, Innovation in the Blue Economy: Realising the Potential of Our Seas and Oceans for Jobs and Growth, СОм (2014) 254 final $/ 2$.

129 European Commission, Report on the Blue Growth Strategy: Towards More Sustainable Growth and Jobs in the Blue Economy, SwD (2017) final.

130 Ibid., 6, citing: 2016 Annual Economic Report on the European Union Fishing Fleet: 'Revenue in 2014: EUR 7.3 billion; net profit in 2014: EUR 770 million; STECF, The 2016 Annual Economic Report on the EU Fishing Fleet (STECF 16-11), <https://stecf.jrc.ec.europa.eu/ documents/43805/1489224/2016_AER_2_STECF_EXECUTIVE+SUMMARY.pdf> accessed 23/11/2017.

131 Ecorys, Deltares and Oceanic Consortium, Blue Growth: Scenarios and Drivers for Sustainable Growth from the Oceans, Seas and Coasts, First Interim Report - Second Revised Version, European Commission DG MARE, 2011, 82. 
There is a contradiction between the Blue Growth agenda which perceives marine fisheries as a legacy industry in terminal decline and the Blue Growth strategy which assesses the sector as in robust economic health. This contradiction is a direct consequence of a market failure in marine fisheries combined with an incoherent policy of regulation that subsidises an industry to overexploit the fish resource for which is does not pay. ${ }^{132}$

\section{1}

\section{Conclusion}

The ecosystem-based management envisaged in the MSFD to protect biodiversity and ecosystems has been marginalised in fisheries management under the CFP. Environmental considerations are routinely trumped by an apparent economic imperative. The social benefits that were expected to flow from the exceptional treatment of the fisheries sector have failed to materialise; jobs are generally poorly paid, the industry is in decline and the fleet has consolidated with profits concentrated in the hands of fewer operators who are now in a position to shape regulatory policy. Fisheries regulation clings to the precautionary approach so that exploitation is permitted right to the margin of biological sustainability with catch entitlements often set in excess of scientific advice. Although ecosystem-based management is required to underpin the regulation of all activities in EU marine waters, its application is to ameliorate the multiplication of stresses on the natural environment as the area is opened up to increasing economic activities. An ecosystem-based approach will render EU seas more sustainable only if the CFP is subjected to the terms of the MSFD and the MSP planners revisit their understanding of ecosystem-based management. Whilst such changes, undoubtedly, would improve the situation, the fact that the resource is free at point of extraction will always pose a threat to its sustainability. Only when subsidies are removed and extractors fully pay for the use of the resource will the fisheries sector be economically and environmentally viable.

\section{Table of Authorities}

\section{International Treaties}

Treaty establishing the European Economic Community, March 25, 1957, 298 UNTS 11

132 J Wakefield, Reforming the Common Fisheries Policy (Edward Elgar, Cheltenham, 2016). 
United Nations Convention on the Law of the Sea (LOSC) (Montego Bay, 10 December 1982, 1833 UNTS 3 )

United Nations Convention on Biological Diversity (СвD) (Rio de Janeiro, 5 June 1992, 31 ILM (1992) 818)

1992 Convention for the Protection of the Marine Environment of the North-East Atlantic (OSPAR) (Paris, 22 September 1992, 2354 UNTS 67)

United Nations Agreement for the Implementation of the Provisions of the United Nations Convention on the Law of the Sea 1982 relating to the Conservation and Management of Straddling Fish Stocks and Highly Migratory Fish Stocks (New York, 4 December 1995, 2167 UNTS 3)

United Nations Convention on Biological Diversity (СвD) (Rio de Janeiro, 5 June 1992, 31 ILM (1992) 818), COP 7 Decision VII/5: Marine and coastal biological diversity. (2004)

\section{International Cases}

Southern Bluefin Tuna Cases (New Zealand v Japan; Australia v Japan) (Provisional Measures) (1999) 38 ILM 1624

Southern Bluefin Tuna Cases (Australia and New ZealandvJapan), Award on Jurisdiction and Admissibility (2000) 39 ILM 1359

\section{EU Instruments}

\section{Treaties}

Consolidated Version Treaty on European Union, OJ 1992 C 325/5

Consolidated version of the Treaty on the Functioning of the European Union, OJ 2012 $\mathrm{C}_{326}$

\section{Regulations}

Regulation (EEC) 2141/70 of the Council of 20 October 1970 laying down a common structural policy for the fishing industry [1970] OJ Spec Ed 703, repealed

Council Regulation (EEC) 170/83 of 25 January 1983 establishing a Community system for the conservation and management of fishery resources [1983] OJ L24/1, repealed Council Regulation (EC) No 1198/2006 on the European Fisheries Fund [2006] OJ L223/1

Regulation (EU) No 1380/2013 of the European Parliament and of the Council on the Common Fisheries Policy, amending Council Regulations (EC) No 1954/2003 and (EC) No 1224/2009 and repealing Council Regulations (EC) No 2371/2002 and (EC) No 639/2004 and Council Decision 2004/585/EC, [2013] OJ L354/22

Regulation (EU) No 508/2014 of the European Parliament and of the Council on the European Maritime and Fisheries Fund and repealing Council Regulations (EC) 
No 2328/2003, (EC) No 861/2006, (EC) No 1198/2006 and (EC) No 791/2007 and Regulation (EU) No 1255/2011 of the European Parliament and of the Council, [2014] OJ L149/1

Commission Regulation 717/2014 on the application of Articles 107 and 108 of the Treaty on the Functioning of the European Union to de minimis aid in the fishery and aquaculture sector, OJ $2014 \mathrm{Ligo} / 45$

Commission Regulation (EU) No 1388/2014 declaring certain categories of aid to undertakings active in the production, processing and marketing of fishery and aquaculture products compatible with the internal market in application of Articles 107 and 108 of the Treaty on the Functioning of the European Union, OJ 2014 $\mathrm{L}_{3} 69 / 37$

\section{Directives}

Council Directive 92/43/EEC on the conservation of natural habitats and of wild fauna and flora [1992] OJ L206/7

Directive 2008/56/EC of the European Parliament and of the Council of 17 June 2008 establishing a framework for community action in the field of marine environmental policy [2008] OJ L164

Directive 2009/147/EC of the European Parliament and of the Council of 30 November 2009 on the conservation of wild birds [2010] OJ L20/7

Directive 2014/89/EU of the European Parliament and of the Council establishing a framework for maritime spatial planning [2014] OJ L257/135

\section{Decisions}

Commission Decision (EU) 2017/848 of 17 May 2017 laying down criteria and methodological standards on good environmental status of marine waters and specifications and standardised methods for monitoring and assessment, and repealing Decision 2010/477/EU (Text with EEA relevance), OJ 2017 L125/43

Decision No 1386/2013/EU of the European Parliament and of the Council of 20 November 2013 on a General Union Environment Action Programme to 2020 'Living well, within the limits of our planet' Text with EEA relevance, OJ 2013 $\mathrm{L}_{354 / 171}$

\section{EU Cases}

Case C-453/o8 Karanikolas and Others [2010] ECR I-7895

Joined Cases T-74, 76, 83-85, 132, 137, 141/oo, Artegodan GmbH and Others v Commission [2002] ECR II-4945

Case C-245/12 Commission v Poland OJ $2008 \mathrm{L164/9}$

Case C-669/16 European Commission v UK, not yet heard 


\section{Bibliography}

\section{Books}

Birnie P, Boyle A, and Redgwell C, 'International Law and the Environment' (Oxford University Press, Oxford, 2008).

Gibbons W and Odum EP, Keeping all the pieces: perspectives on natural history and the environment (Smithsonian Institution Press; Washington, DC: 1993).

Stephens T, International Courts and Environmental Protection (Cambridge University Press, Cambridge, 2009).

Wakefield J, Reforming the Common Fisheries Policy (Edward Elgar, Cheltenham, 2016).

\section{International Policy Documents}

Rio Declaration on Environment and Development (Rio de Janeiro, 14 June 1992, UN Doc. A/CONF.152/26 (vol. 1) reprinted in 31 ILM 874 (1992).

UN Food and Agriculture Organisation, Code of Conduct for Responsible Fisheries, Rome, FAO. 1995.

ICES, Special Request, EU-Norway request to ICES on increasing the 2014 TAC for cod in the North Sea - Additional reply to part of the original request, Advice March 2014.

\section{EU Policy Documents}

Communication from the Commission on the precautionary principle, Сом (2000) 1 final.

Communication from the Commission to the European Parliament, the Council, the European Economic and Social Committee and the Committee of the Regions - An Integrated Maritime Policy for the European Union, Сом (2007) 575 final.

Communication from the Commission to the Council and the European Parliament The role of the CFP in implementing an ecosystem approach to marine management [SEC(2008) 449] COM (2008) 187 final.

Eurostat, Facts and Figures on the CFP (Luxembourg, 2008).

European Commission, Green Paper on the Reform of the Common Fisheries Policy сом (2009) 163 .

Ecorys, Deltares and Oceanic Consortium, Blue Growth: Scenarios and Drivers for Sustainable Growth from the Oceans, Seas and Coasts, First Interim Report - Second Revised Version, European Commission DG MARE, 2011.

Communication from the Commission to the European Parliament, the Council, The European Economic and Social Committee and the Committee of the Regions, Blue Growth Opportunities for Marine and Maritime Sustainable Growth, сом (2012) 494 final. 
Report from the Commission to the Council and the European Parliament, 'Contribution of the Marine Strategy Framework Directive (2008/56/EC) to the implementation of existing obligations, commitments and initiatives of the Member States or the EU at EU or international level in the sphere of environmental protection in marine waters', Сом (2012) 662 final.

North Sea Regional Advisory Council, Response from the North Sea Regional Advisory Council - Consultation on Future Role and Composition of Advisory Councils, Position Paper 3 (2012/13).

Background Document to the draft Joint Recommendation for Offshore Fisheries Management on the International Dogger Bank under the revised Common Fisheries Policy, The Hague, Bonn, London, 31 May 2016.

Eurostat, Agriculture, forestry and fishery statistics, 2016.

Scientific, Technical and Economic Committee for Fisheries, The 2016 Annual Economic Report on the EU Fishing Fleet (STECF 16-11).

European Commission, Report on the Blue Growth Strategy: Towards More Sustainable Growth and Jobs in the Blue Economy, SwD (2017) final.

\section{Other Official Publications}

Brown J, 'Fisheries' in OECD, Subsidy Reform and Sustainable Development, (OECD 2007) 111-119.

Davies CE and others, 'EUNIS Habitat Classification Revised 2004', (http://eunis.eea .europa.eu/upload/EUNIS_2004_report.pdf) accessed 6 March 2014.

Hommes S and others, Report on cross-border Maritime Spatial Planning in two case studies, MASPNOSE 2012.

Rashid Sumaila U and others, Global Fisheries Subsidies, October 2013, IP/B/PECH/2013146, 24, <www.europarl.europa.eu/RegData/etudes/note/join/2013/513978/IPOLPECH_NT(2013)513978_EN.pdf> accessed 20/11/2017.

Reker J and others, European Environmental Agency, 'Marine protected areas in urope's seas: An overview and perspectives for the future' EEA Report, No 3/2015 (European Environmental Agency 2015).

Rodust U, Draft Report on the proposal for a regulation of the European Parliament and of the Council on the Common Fisheries Policy, 2011/0195(COD).

\section{Book Chapters}

Dreyer M and Sellke P, 'The Regional Advisory Councils in European Fisheries: An Appropriate Approach to Stakeholder Involvement in an EU Integrated Marine Governance?' in Gilek M and Kern K (eds), Governing Europe's Marine Environment: Europeanization of Regional Seas or Regionalization of EU Policies? (Routledge, Abingdon, 2015) 121-140. 


\section{Journal Articles}

Costello MJ and Wilson SP, 'Predicting the number of known and unknown species in European seas using rates of description: Predicting species diversity', (2011) 20 Global Ecology and Biogeography 319.

Cucknell A-C and others, 'Harbour porpoise (Phocoena phocoena) presence, abundance and distribution over the Dogger Bank, North Sea, in winter' (2017) 7 Journal of the Marine Biological Association of the UK, 1455.

Fenichel E and others, 'Real Options for Precautionary Fisheries Management' (2008) Fish and Fisheries 121.

Ludwig D, Hilborn R and Walters C, 'Uncertainty, resource exploitation and conservation: Lessons from history' (1993) 26o Science 36.

O'Leary BC and others, 'Fisheries Mismanagement' (2011) 62 Marine Pollution Bulletin 2642.

Pauly D, 'Anecdotes and the shifting baseline syndrome of fisheries' (1995) 10 Trends in Ecology \& Evolution 430.

Pauly D and others, 'Towards sustainability in world fisheries' (2002) 418 Nature 689.

Peng C, Zhao X and Liu G, 'Noise in the Sea and Its Impacts on Marine Organisms' (2015) 12 International Journal of Environmental Research and Public Health 12304. Pérez-Ruzafa A, Garcia-Charton J and Marcos C, 'North East Atlantic vs. Mediterranean Marine Protected Areas as Fisheries Management Tool', Frontiers of Marine Science, 3 August 2017, <https://doi.org/10.3389/fmars.2017.00245 > accessed 20/11/2017.

Pitcher T, 'Fisheries Managed to Rebuild Ecosystems? Reconstructing the Past to Salvage the Future' (2001) 11 Ecological Applications 601.

Sabatier P, 'Social Movements and Regulatory Agencies: Towards a More Adequate and Less Pessimistic - Theory of "Clientielle-capture" (1975) 6 Policy Sciences 301. 